\title{
Editorial: Introducing Incoming Editor-in-Chief, Richard S. Balkin
}

\author{
Richard S. Balkin ${ }^{1}$ \\ Published online: 5 May 2020 \\ (C) Springer Science+Business Media, LLC, part of Springer Nature 2020
}

\begin{abstract}
The International Journal for the Advancement of Counselling has been in publication since 1978. Incoming Editor-in-Chief, Richard S. Balkin, Ph.D., LPC, NCC is introduced. The editorial covers an explanation of standards and growth for the journal, including expectations in terms of publication content, scope of articles, and goals for increasing journal impact.
\end{abstract}

Keywords Publication · Counselling $\cdot$ Journal $\cdot$ International $\cdot$ Impact

I am honored to serve in the role of Editor-in-Chief for the International Journal for the Advancement of Counselling. The journal is an international resource to inform the counselling profession through the publication of articles that address counselling practice, theory, training, supervision, policy, trends, and research. Sacra and Nichols (2018) discussed internationalization in counselling, particularly from countries in which counselling resources are disparate, as a culturally respective process to empower multi-national communities in the promotion of essential components of counselling - mental health, wellness, education, and career goals (Kaplan et al. 2014). Clearly, scholarship is pertinent to promoting evidence-based, cuttingedge research to the counselling profession. Scholarship that addresses mental health needs across the globe, such as human trafficking (Thompson and Haley 2018); implementation of models for school counselling for countries with limited resources (Kiweewa et al. 2018); or the effect of the global financial crisis on adolescents in a specific country (Brouzos et al. 2015) serve as exemplars of research that can have high impact and transform counselling internationally. Through an affiliation with the International Association for Counselling and abstracting and indexing through prominent library databases, such as APA PsycINFO, the International Journal for the Advancement of Counselling engages with an active readership with interest in promoting counselling globally.

Richard S. Balkin

rsbalkin@olemiss.edu

1 University of Mississippi, 120 Guyton Hall, Oxford, MS, USA 
Articles published in the International Journal for the Advancement of Counselling will generally fall into three categories: (a) research, (b) assessment and evaluation, and (c) theory and practice. Research includes a variety of data-driven analyses including quantitative, qualitative, mixed method, and single case research design approaches. Assessment and evaluation may include development of novel measures for use in counselling practice or establishment of valid instruments from representative, international, target populations. Methods of program evaluation, either in counselling agencies or programs, as well as academic settings, are welcome. Theory and practice areas of interest include techniques, interventions, trends, or policies that impact counselling practice or the counselling profession. Researchers should take care to address implications to counselling across diverse, multinational perspectives.

Goals for the Journal include increasing submissions and the number of articles published in each issue. Both of these goals are consistent with achieving additional listings in scholarly databases, increasing scholarly citations of the journal, and ranking with a journal impact factor. Publication in the International Journal for the Advancement of Counselling not only serves the counselling profession but serves faculty and researchers who wish to publish their work and engage in the broader academic community. Please consider submitting your manuscripts to the International Journal for the Advancement of Counselling as an outlet to publish and promote your scholarship.

To prepare manuscripts for submission, authors are required to use the Publication Manual of the American Psychological Association to develop their manuscripts. Authors should be particularly attentive to abstracts and page limits, as a comprehensive abstract limited to 150 words can be helpful in developing an understanding for the article and increasing the likelihood of citations. Research manuscripts in particular should include an abstract that covers a brief overview of the topic, the target population, the type of analysis, the findings, and a statement central to the importance of the finding. Research manuscripts should not exceed 35 pages with references; conceptual manuscripts should not exceed 25 pages with references. Exceptions will be considered for submissions of meta-analyses and systematic reviews. For quantitative research, authors are encouraged to address statistical, practical, and, when appropriate, clinical significance; validity of instruments, reliability of scores on the instruments, and statistical power. For qualitative research, authors are encouraged to address purposeful sampling strategies employed, theoretical sensitivity, trustworthiness, and coding processes.

I would like to close by acknowledging the work of Gary Hermansson, who served as Editor-in Chief of the International Journal for the Advancement of Counselling for the past 16 years. I am appreciative of the hard work and dedicated individuals at Springer, in particular Carol Bischoff, for work in transitioning and promoting this journal. I also want to acknowledge and welcome Drs. Donna Sheperis, Quentin Hunter, Mehmet Karaman, and Erika Schmit, who bring their collective expertise in Qualitative Research, Quantitative Research, Assessment and Evaluation, and Theory and Practice as Associate Editors to the International Journal for the Advancement of Counselling. The Role of Editor-inChief of International Journal for the Advancement of Counselling is a service position, and therefore, I welcome opportunities to discuss how this journal may continue to strengthen and be a resource to the counseling profession. I may be reached at rsbalkin@olemiss.edu 


\section{Compliance with Ethical Standards}

Conflict of Interest I have no known conflict of interest to disclose.

\section{References}

Brouzos, A., Vassilopoulos, S., Korfiati, A., \& Baourda, V. (2015). Secondary school students' perceptions of their counselling needs in an era of global financial crisis: An exploratory study in Greece. International Journal for the Advancement of Counselling, 37(2), 168-178. https://doi.org/10.1007/s10447-015-9235-6.

Kaplan, D. M., Tarvydas, V. M., \& Gladding, S. T. (2014). 20/20: A vision for the future of counseling: The new consensus definition of counseling. Journal of Counseling \& Development, 92, 366-372. https://doi. org/10.1002/j.1556-6676.2014.00164.x.

Kiweewa, J. M., Knettel, B. A., \& Luke, M. M. (2018). Incorporating comprehensive counselling and guidance models into school curricula in sub-Saharan Africa. International Journal for the Advancement of Counselling, 40(2), 133-147. https://doi.org/10.1007/s10447-017-9316-9.

Sacra, M. M., \& Nichols, L. M. (2018). Globalization and internationalization: The implications on the mental health field in Bhutan. International Journal for the Advancement of Counselling, 40(4), 443-454. https://doi.org/10.1007/s10447-018-9336-0.

Thompson, J., \& Haley, M. (2018). Human trafficking: Preparing counselors to work with survivors. International Journal for the Advancement of Counselling, 40(3), 298-309. https://doi.org/10.1007 /s10447-018-9327-1.

Publisher's Note Springer Nature remains neutral with regard to jurisdictional claims in published maps and institutional affiliations. 